\title{
The effect of a super-oxidized solution on the bladder uroepithelium of rats
}

\section{El efecto de una solución superoxidada sobre el uroepitelio de la vejiga de ratas}

\author{
(iD) Yael Atziri Pérez-Salas, ${ }^{1}$ (iD)Alfonso Galván-Montaño, ${ }^{1}$ iD Ana Lilia Morales-Leyte, ${ }^{1}$ \\ (iDMaría de Lourdes Suárez-Roa, ${ }^{1}$ iD Gloria León-Ávila, ${ }^{2}$ iD Silvia García-Moreno, ${ }^{1}$ \\ iD Luz Elena Espinosa de los Monteros-Pérez. ${ }^{1}$
}

Key words: Superoxide, disinfectant, urinary bladder, rat, 16S rRNA, UTIs

Autor de correspondencia:

*Luz E. Espinosa de los Monteros Pérez Dirección: Hospital General "Dr. Manuel Gea González”, Av. Calzada de Tlalpan \#4800, Col. Sección XVI, Tlalpan,

CP 14080, Ciudad de México, México. Correo electrónico: espinosaluzelena@ gmail.com

\section{Abstract}

Aim: The present study aimed to identify the changes on the bladder mucosa in rats after intravesical infusion of Super-oxidized solution (SOS) (Mycrodacyn60® Mexico).

Design: Eighteen Wistar Albino rats weighing 250-300 g were randomly categorized into three groups. Rats in Group 1 were infused with a single dose of $1.5 \mathrm{ml}$ of $0.9 \%$ saline solution (SS) whereas those in group 2 were administered a single dose of $1.5 \mathrm{ml} \mathrm{pH}$ neutral SOS. Control rats in Group 3 did not undergo any procedure.

Results: The absence of bacteria was verified before and after the administration of the solution, performing urine cultures and amplifying the 16S rRNA fragment by PCR and histopathological examinations for each bladder. The absence of bacterial DNA in the uroepithelium was demonstrated, histopathological examination revealed, that irrigation with SOS, in histological observation, no structural alterations were identified in the urothelial mucosa.

Limitations: It was not possible to analyze the effect of SOS absorption indamage to the uroepithelium secondary to traumatic infection or injury. The effect of irrigation at different times and volumes with SOS was also not analyzed.

Originality: It is known that SOS is useful as disinfectant in skin and serosa bacterial infections, lacking toxicity and it is effective against Escherichia coli. The use of superoxide solutions in cavities such as the bladder, has not been investigated yet.

Conclusion: The pH-neutral SOS infused transurethral in the bladder of rats has no adverse effects on the uroepithelium, which was supported by histopathological evidence.

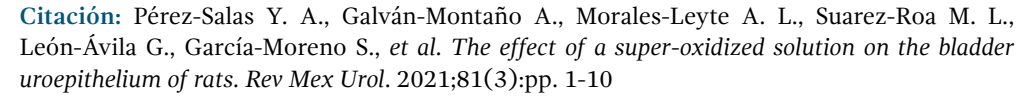

Citación: Pérez-Salas Y. A., Galván-Montaño A., Morales-Leyte A. L., Suarez-Roa M. L., León-Ávila G., García-Moreno S., et al. The effect of a super-oxidized solution on the bladder uroepithelium of rats. Rev Mex Urol. 2021;81(3):pp. 1-10

${ }^{1}$ Secretaría de Salud, Hospital General “Dr. Manuel Gea González”, Ciudad México, México.

${ }^{2}$ Instituto Politécnico Nacional, Escuela Nacional de Ciencias Biológicas, Ciudad de México, México.

Recibido: 5 de mayo de 2020

Aceptado: 30 de junio de 2021

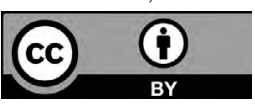




\section{El efecto de una solución superoxidada sobre el uroepitelio de la vejiga de ratas. Pérez-Salas Y. A., et al.}

\section{Resumen}

Objetivo: El presente estudio tuvo como objetivo identificar los cambios en la mucosa de la vejiga en ratas luego de la infusión intravesical de solución superoxidada (SOS) (Mycrodacyn60® México).

Diseño: Dieciocho ratas Wistar Albino que pesaban 250-300 g se clasificaron aleatoriamente en tres grupos. A las ratas del grupo 1 se les infundió una dosis única de $1,5 \mathrm{ml}$ de solución salina (SS) al $0.9 \%$, mientras que a las del grupo 2 se les administró una dosis única de 1.5 $\mathrm{ml}$ de $\mathrm{pH}$ neutro SOS. Las ratas de control del Grupo 3 no se sometieron a ningún procedimiento.

Resultados: Se verificó la ausencia de bacterias antes y después de la administración de la solución, realizando urocultivos y amplificando el fragmento de ARNr 16S mediante PCR y exámenes histopatológicos de cada vejiga. Se demostró la ausencia de ADN bacteriano en el uroepitelio, el examen histopatológico reveló que la irrigación con SOS, en observación histológica, no se identificaron alteraciones estructurales en la mucosa urotelial.

Limitaciones: No fue posible analizar el efecto de la absorción de SOS en el daño al uroepitelio secundario a una infección o lesión traumática. Tampoco se analizó el efecto del riego en diferentes momentos y volúmenes con SOS.

Originalidad: Se sabe que SOS es útil como desinfectante en infecciones bacterianas cutáneas y serosas, carece de toxicidad y es eficaz contra Escherichia coli. El uso de soluciones de superóxido en cavidades como la vejiga aún no se ha investigado.

Palabras clave: Superóxido, desinfectante, vejiga urinaria, rata, 16S rRNA, UTIs
Conclusiones: El transuretral infundido con SOS de $\mathrm{pH}$ neutro en la vejiga de ratas no tiene efectos adversos sobre el uroepitelio, lo cual fue apoyado por evidencia histopatológica.

\section{Introduction}

The super-oxidized solution (SOS) is a neutral $\mathrm{pH}$ solution that has a powerful disinfectant activity, ${ }^{(1)}$ antiseptic effect of SOS has been reported in patients with second and third degree burns, cleaning of superficially infected wounds. ${ }^{(2,3)}$.

Superoxide solutions (SOS) are electrochemically processed solutions, which are prepared using sterile water and sodium chloride $(\mathrm{NaCl})$. Water molecules are split during electrolysis and form active molecules of chlorine and oxygen, such as hypochlorite, hypochlorous acid, sodium chloride, oxidized water, with $\mathrm{pH}$ between 6.2 and 7.8 , a potential oxide reduction $>800 \mathrm{mV}$, with an osmolarity of $13 \mathrm{mOsm} / \mathrm{kg} .{ }^{(4)}$

There are several studies that show that SOS, possess antimicrobial activity towards 
multidrug-resistant strains (MDR), viruses, fungi and spores as well as reports of its use in cases of perforated appendicitis with beneficial effects, ${ }^{(5,6)}$ used in patients with pelviperitonitis, demonstrated that it did not cause lesions of these tissues, ${ }^{(5)}$ including an experimental study in rats about tissues of the uterus and ovary without any histopathological evidence of adverse toxic reaction and structural deterioration within endometrial glands and myometrial tissue. ${ }^{(6)}$

Administration has been performed in experimental animals, including a bovine root canals were prepared and inoculated with $\mathrm{E}$. faecalis after incubation, were irrigated using three solutions inclusive a SOS, which significantly presented antimicrobial action. ${ }^{(7)}$

Zinkevich V. et al., in $2000,{ }^{(8)}$ demonstrated that super-oxidized water (Sterilox ${ }^{\circledR}$ ) acts upon E. coli JM109 by damaging double stranded DNA, RNA and proteins. Most probably, oxidizing chemicals in the compound destroy the covalent bonds in the nucleic acid chains, as well as in the protein chains, revealed that after 30s of exposure, E. coli considerably increased in size.

No intact bacterium was seen after $5 \mathrm{~min}$ of exposure, but a large amount of debris attributed to cytoplasmic material resulting from bacterial lysis was noted.

The present study aimed to identify the changes on the bladder mucosa in rats after intravesical infusion of SOS, based on observations by Zinkevich V. et al., in $2000{ }^{(8)} \mathrm{We}$ propose that in 10 minutes of exposure, with SOS, it will be enough to penetrate a bacterium, interfering with its metabolic activity and causing structural damage, therefore, it will allow evaluating the effect of SOS on urothelial tissue.
The following research hypothesis (HI) and null hypothesis (HO) are proposed.

$\mathrm{HI}=$ The frequency of edema in the lamina propria is different in the three groups.

$\mathrm{HO}=$ The frequency of edema in the lamina propria does not differ in the three groups.

\section{Material and methods}

Ethical statement: All the rats were selected and treated according to the guide-lines of the National Advisory Committee for Laboratory Animal Research (NACLAR, 2004) and approved by the Committee of Research and Ethics in Investigation (Number: 12-08-2017), ${ }^{(9)}$ they were managed under constant conditions of temperature and humidity, with cycles of 12 hours of light for 12 hours of darkness according to the Official Mexican Standard; NOM-062-ZOO-1999 (Diario Oficial Mexicano 2001), ${ }^{(10)}$ in the bioterium of the Hospital General "Dr. Manuel Gea González “.

Study design: The sample estimation was made according to the formula proposed by Alejandro Rojo, in 2014, ${ }^{(11)}$ in accordance to the ethics committee in animal experimentation of the Vall d'Hebron Research Institute VHIR HUVH.

Population Animals: Eighteen Wistar rats, selected from the bioterio of the Hospital General, that met the selection criteria (female, weighing 250-300g, aged 10-12 weeks, clinically healthy), in which the absence of bacteria was proved via bacteriological culture, done prior to the instillation of the solutions, with the collection of the urine sample in a container under sterile conditions and transported at $4^{\circ}$ $\mathrm{C}$ to the microbiology laboratory. 
Were randomized into 3 groups ( 6 for each group; two experimental with SS and SOS and control group not infused).

Group 1: A bladder infusion was administered through a single transurethral dose of $1.5 \mathrm{ml} 0.9 \%$ saline (SS) (Baxter ${ }^{\circledR}$ Mexico); the solution was retained in the bladder for $10 \mathrm{~min}$, and the catheter was subsequently removed.

Group 2: The rats were administered a single dose of $1.5 \mathrm{ml}$ SOS as described above.

Group 3: The rats that did not undergo any treatment and were assigned to the control group.

After 24 hours, under general anaesthesia, transurethral catheterization is again performed for a second urine sample and the infusion for 10 minutes of the SOS, saline solution and catheterization without infusion. Subsequently the rats were sacrificed, macroscopic analyses of each bladder was carried out to detect any change including adhesions or ulcerations. The bladder was divided in two longitudinal sections. A section for blinded microbiological and molecular studies to find bacterium absence, and another was preserved in $10 \%$ formaldehyde (JT Baker ${ }^{\circledR}$ ) for the blinded histopathological analysis.

\section{Experimental procedures}

\section{Anesthesia}

The rat was placed in the polycarbonate box and semi-automatic inhalation induction was performed with the Enfluratec 3 device, Ohmeda BOC Health care in one with a dose of isoflurane of $2-4 \% / 98-96 \%$ of $\mathrm{O} 2$ at $1-2 \mathrm{~L} /$ min, once under clinical anesthesia, the rat was placed supine in the surgical table on a sterile field and general anesthesia was maintained by means of a silicone neonate mask with a dose of 1 to $2.5 \% / 99-97.5 \% \mathrm{O} 2$ at $0.5 \mathrm{~L} / \mathrm{min}$.

\section{Urethral catheterization}

Antiseptic technique was used with a $0.7 \%$ iodine solution-74\% isopropyl alcohol in the abdominal pelvic area, the urethra was located by retracting it with Adson tweezers without teeth at a $90^{\circ}$ angle, a catheter was installed transurethral using the polyurethane sheath of a 24 Gauge x $19 \mathrm{mM}$ sterile peripheral venous catheter, which was lubricated with sterile water, gently introduced at a 90o angle when resistance was found, the catheter was moved caudally at an angle of $270 \mathrm{o}$ and continue its introduction until the length of the catheter is completed.

\section{Vesical infusion}

A $20 \mathrm{G}$ x $32 \mathrm{mM}$ needle was placed in a $3 \mathrm{~mL}$ syringe and $1.5 \mathrm{~mL}$ of the substance to be irrigated was taken (SOS, $0.9 \%$ saline), the needle was removed and the syringe was connected to the previously installed transurethral catheter, slowly proceeded to irrigate the bladder with the solution, the syringe was left connected to the catheter for a period of 10 minutes avoiding the spontaneous emptying of the bladder, at the end of the period the catheter was removed.

\section{Cystectomy}

Under general anesthesia, the abdominal midline was incised to expose the abdominal cavity 
El efecto de una solución superoxidada sobre el uroepitelio de la vejiga de ratas. Pérez-Salas Y. A., et al.

and performed a cystectomy. The extracted bladder was divided into two parts, one of them was placed in a sterile Eppendorf tube that was marked and placed in the cold vehicle for microbiological and molecular analysis. The other half was deposited in another tube labeled with $1 \mathrm{ml}$ of $10 \%$ formalin for histopathological analysis.

\section{Sacrifice of rats}

The rats were placed in the induction box, in which the sacrifice was made by chemical method with carbon dioxide, once the death of the rat was verified by vital signs. The carcasses of dead rats were handled in accordance with the Official Mexican Standard; NOM-087ECOL-SSA1-2002 (Diario Oficial Mexicano, 2002), ${ }^{(12)}$ deposited in yellow bags and transported to the Hospital Waste Depository.

\section{Microbiological analysis}

Tissue samples and $50 \mu$ urine were cultured on Mueller Hinton (BD ${ }^{\circledR}$ agar plates) for $24 \mathrm{~h}$ at $37^{\circ} \mathrm{C} .{ }^{(13)}$

\section{Molecular analysis}

Deoxyribonucleic acid (DNA) was extracted using cetyltrimethylammonium bromide (CTAB SIGMA®) technique and quantified using NanoDrop Onec (Thermo Scientific). (14) To verify that DNA samples were not contaminated with bacterial DNA, PCR reaction was performed using universal eubacterial primers (BIOSEARCH technologies ${ }^{\circledR}$ ):
Eub338F 5'-ACTCCTACGGGAGGCAGCAG-3' y Eub518 R 5'-ATTACCGCGGCTGCTGG-3. ${ }^{(15)}$

Each reaction was performed in a final volume of $25 \mu$, including 15 pmol primers, dNTPs (SIGMA®), and $3.0 \mathrm{mM} \mathrm{MgCl2(QARTA}$ $\left.{ }^{\circledR}\right), 1 \mathrm{U}$ Taq DNA polymerase (QARTA ${ }^{\circledR}$ ) and $258 \mathrm{ng} / \mu \mathrm{l}$ DNA. The cycles used were 1 cycle at $95^{\circ} \mathrm{C}$ for $5 \mathrm{~min}, 34$ cycles at $94^{\circ} \mathrm{C}$ for $30 \mathrm{~s}, 1$ min at $62^{\circ} \mathrm{C}, 1 \mathrm{~min}$ and $30 \mathrm{~s}$ at $72^{\circ} \mathrm{C}$ and a final extension at $72^{\circ} \mathrm{C}$ for $5 \mathrm{~min}$, in a thermocycler (Biorad ${ }^{\circledR}$ ). The expected amplicon was $200 \mathrm{pb}$, $5 \mu$ of products were electrophoresed through $1.5 \%$ agarose gel (Molecular Biology Grade ${ }^{\circledR}$ ) and stained with ethidium bromide (SIGMA ${ }^{\circledR}$ ).

\section{Histology}

For histopathological analysis the bladder samples were fixed with $10 \%$ formaldehyde (JT Baker $\left.{ }^{\circledR}\right)$, dehydrated, and embedded in paraffin (Paraplast ${ }^{\circledR}$ ). Two cuts per sample were analyzed and tissues were sliced into $3 \mu \mathrm{m} \mathrm{sec-}$ tions and stained with haematoxylin and eosin and examined under a light microscope (Olympus BX40®), at $400 \mathrm{x}$ magnification. ${ }^{(16)}$ The analysis was carried out by a pathologist and the qualitative evaluation was only divided into present or absent. To simplify the analysis, the histological change was presented as present or absent, nothing intermediate, two sections were analyzed by samples of cross sections of the tissue.

\section{Statistical analysis}

For the comparison of groups, the Chi-square test was used. The level of significance to reject the null hypothesis (Ho) was $\mathrm{p}<0.05$. 
The data was captured with the Microsoft Excel program and will be analyzed with the statistical program SPSS v18.0 (SPSS, Inc., Chicago, IL).

\section{Results}

Including 18 female rats which met the selection criteria and in which the absence of bacteria was verified through bacteriological culture, showed that the urine samples and bladder tissue were not contaminated with bacteria. These results were confirmed by PCR; all the amplifications were negative for samples from the three experimental groups of the 16S rRNA was noted only in the positive control. (Figure 1).

Figure 1. 16S rRNA PCR

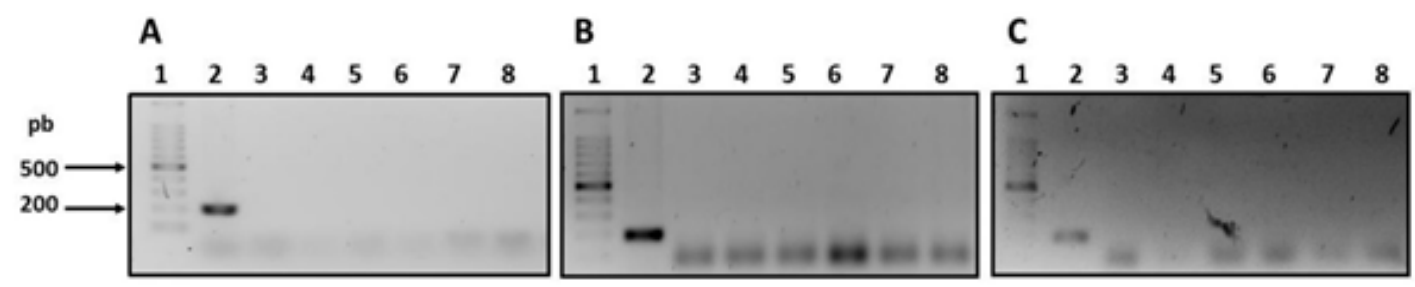

Panel A: rat bladders with saline solution; B: rat bladders with SOS and C: control. Line 1: 100 bp DNA ladder; line 2: Positive control (E. coli strain CFT-073); lines 3 to 8 PCR from each group.

The macroscopic examination of the three groups did not reveal any changes in the abdominal organs (Figure 2).

Figure 2. Macroscopic examination of bladders

A

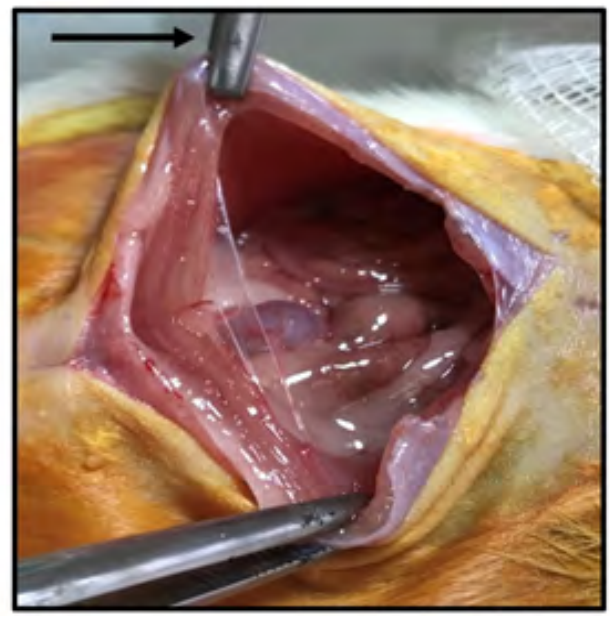

B

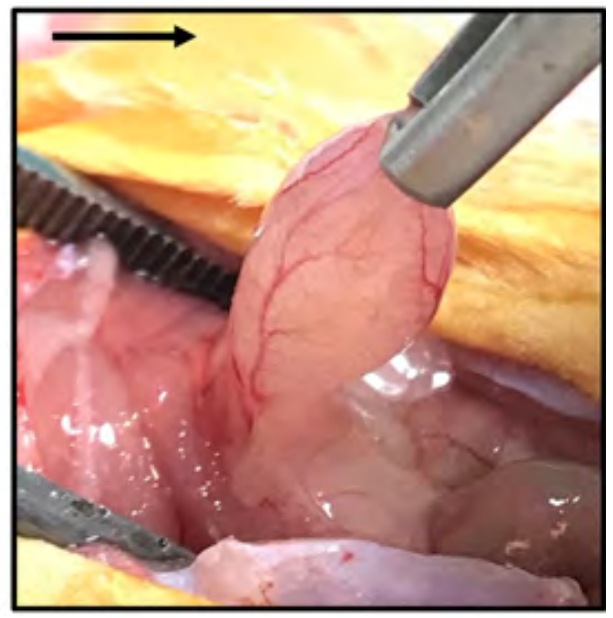

A and B: The bladder receives an infusion of $1.5 \mathrm{ml} \mathrm{0.9 \%} \mathrm{saline} \mathrm{solution.} \mathrm{Vascular} \mathrm{paths} \mathrm{become} \mathrm{apparent} \mathrm{due} \mathrm{to} \mathrm{congestion}$ due to the pinching process. Abdominal midline was incised, the arrow indicates the orientation. 
To identify damage in the uroepithelium histologically, ours was considered as criteria; the presence of lamina propria edema, umbrella cell edema, damage to the structure of the epithelium, congestion and vascular and the macroscopic examination showed the following.

Group 1: Saline Solution irrigation

Upon analysis of the histological section, no structural changes were identified in the urothelium, only the increase in the volume of the cytoplasm and of the nucleus of the umbrella cells is notable. There is discrete vascular congestion in the lamina propria (Figure 3A).

In the histological section, vesical mucosa consisting of elliptical umbrella cells and uro- thelium that do not present cytological alterations is identified. The connective tissue of the lamina propria is observed intact (Figure 3B).

The histological analysis, rat bladder mucosa is identified, which is composed of transitional epithelium (uroepithelium or urothelium), integrated of a stratified epithelium composed of cubic or flat cells with a variable thickness of two to three layers; on the surface there is an umbrella-shaped layer of cells with an elliptical shape and an eosinophilic cytoplasm and a round nucleus. The lamina propria is made up of connective tissue with collagen fibers and blood vessels (Figure 3C).

Figure 3. Histopathological examination of bladder tissue of the three groups stained with haematoxylin-eosin
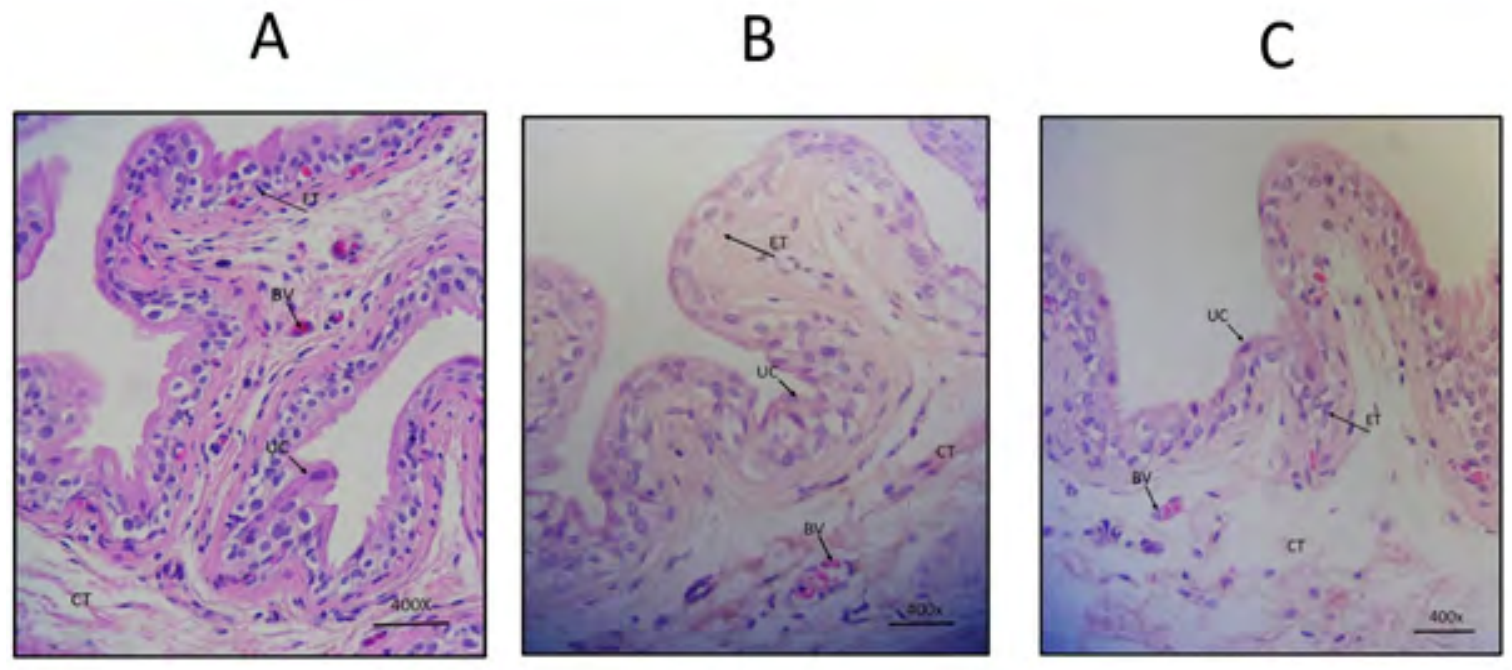

A) Saline Solution, B) Irrigation with SOS, C) Control without irrigation. ET: epithelial tissue, CT: connective tissue, MT: muscular tissue, UC: umbrella cells and BV: blood vessel.

\section{Statistical analysis}

With a probability of error of $0.01 \%$ the frequency of edema in umbrella cells, only the group exposed to SS was observed in $100 \%$, with a statistical significance $\mathrm{p}<0.0001$. With a probability of error of $0.9 \%$, the frequency of vascular congestion occurs in the group exposed to SS was $\mathrm{p}<0.009$. 


\section{Discussion}

To our knowledge, there is no study evaluating the effect of super oxidized solutions on the bladder or urothelium, the SOS used in this study, was able to demonstrate that bladder washes with SOS do not produce toxicity and that this finding coupled with the existing antecedents of the antimicrobial effect. ${ }^{(17)}$

There are studies that have shown that SOS is a useful adjuvant therapy in peritonitis of any cause along with normal saline the study demonstrates that SOS is safe and effective in reducing postoperative complications such as wound infection, pain, and therefore early recovery, ${ }^{(18)}$ but it does not demonstrate whether there is histological tissue damage, unlike ours, in which it is shown, that can be used without causing damage to the bladder tissues.

Currently, it is used in hospital equipment due to its beneficial effect on microorganisms as a disinfectant. ${ }^{(19)}$ However, the first superoxidized solutions used contained aqueous acid and had a toxic and dangerous role for human tissues.

The new generation of SOS solutions has a neutral $\mathrm{pH}$ with a longer shelf life (> 12 months) than previous superoxide solutions. These new generation SOS are indicated for the topical treatment of chronic and acute wound infections, such as diabetic ulcers, without referring to toxicity effects in the organism. ${ }^{(20)}$ There is limited data on the use of SOS with neutral $\mathrm{pH}$ in intraperitoneal organs. ${ }^{(21)}$

Our rat model allowed us to evaluate the absence of histological damage at the level of the uroepithelium with the use of SOS. No studies have investigated the intravesical use of SOS at the histological level and that it could be an alternative for the treatment and prevention of urinary tract infections (UTI), due to the use of transurethral catheters. ${ }^{(2,3)}$

Has been shown that the use of antimicrobial therapy increases multi-drug resistant bacteria in patients with transurethral catheters. (22) Therefore, the use of intravesical irrigation has been attempted using different substances (saline solution; acetic acid dilutions; antibiotic solutions, including neomycin and polymyxin), reducing the number of bacterial CFUs and white blood cell count without eradicating the infection. ${ }^{(23)}$

In our model it was possible to appreciate that the use of $0.9 \%$ saline solution causes the increase in the volume of the cytoplasm and of the nucleus of the umbrella cells is notable. There is discrete vascular congestion in the lamina propria, probably because they are part of the cellular response to a stimulus, in this case it could be the slight hypertonicity of the saline solution, with respect to the interior of the cell, we have not found that this adverse effect has been reported so far.

Therefore, having demonstrated the absence of damage to the uroepithelium in the rat model with SOS, opens a new perspective of management in urinary tract infections, relying on the effect of the bactericidal activity that it has and that could be demonstrated through the model with urinary infection induced by strains of E. coli uropathogens. Including the possibility of analysing the effect of biofilm producing strains and subsequently assessing the effect of SOS on human uroepithelium, likewise SOS knowledge about human epithelium is not available.

However, we found no evidence in the literature of whether there is any risk of systemic absorption of the SOS solution, or any damage to the uroepithelium secondary to a traumatic 
infection or injury, however, could be analysed in the future.

\section{Conclusions}

The pH-neutral SOS infused transurethrally in the bladder of rats has no adverse effects on the uroepithelium, which was supported by histopathological evidence. However, infusion with $0.9 \%$ saline solution increased the edema of lamina propria and of the umbrella cells, as well as, cytoplasm congestion, and vascular dilatation.

\section{Financial disclosure}

No financial support was received in relation to this article.

\section{Conflict of interest}

The authors declare that there is no conflict of interest.

\section{References}

1. Hadi SF, Khaliq T, Bilal N, Sikandar I, Saaiq M, Zubair M, et al. Treating infected diabetic wounds with superoxidized water as antiseptic agent : a preliminary experience. J Coll Physicians Surg Pak. 2007;17(12):740-3. doi: 12.2007/JCPSP.740743

2. You HS, Fadriquela A, Sajo MEJ, Bajgai J, Ara J, Kim CS, et al. Wound Healing Effect of Slightly Acidic Electrolyzed Water on Cutaneous Wounds in Hairless Mice via Immune-Redox
Modulation. Biol Pharm Bull. 2017;40(9):142331. doi: 10.1248/bpb.b17-00219

3. Landa-Solis C, González-Espinosa D, GuzmánSoriano B, Snyder M, Reyes-Terán G, Torres K, et al. Microcyn: a novel super-oxidized water with neutral $\mathrm{pH}$ and disinfectant activity. J Hosp Infect. 2005;61(4):291-9. doi: 10.1016/j. jhin.2005.04.021

4. Kraft A. Electrochemical Water Disinfection: A Short Review. Platinum Metals Review. 2008 Jul 31;52(3):177-85. doi: 10.1595/147106708X329273

5. Kubota A, Goda T, Tsuru T, Yonekura T, Yagi M, Kawahara H, et al. Efficacy and safety of strong acid electrolyzed water for peritoneal lavage to prevent surgical site infection in patients with perforated appendicitis. Surg Today. 2015;45(7):876-9. doi: 10.1007/s00595014-1050-x

6. Aras A, Karaman E, Çim N, Yıldırım S, Kızıltan R, Yılmaz Ö. The effect of super-oxidized water on the tissues of uterus and ovary: An experimental rat study. Eastern J Med. 2017;22(1):15-9. doi: 10.5505/ejm.2017.42714

7. Rossi-fedele G, de Figueiredo JAP, Steier L, Canullo L, Steier G, Roberts AP. Evaluation of the antimicrobial effect of super-oxidized water (Sterilox ${ }^{\circledR}$ ) and sodium hypochlorite against Enterococcus faecalis in a bovine root canal model. J Appl Oral Sci. 2010;18(5):498-502. doi: 10.1590/S1678-77572010000500012

8. Zinkevich V, Beech IB, Tapper R, Bogdarina I. The effect of super-oxidized water on Escherichia coli. Journal of Hospital Infection. 2000;46(2):153-6. doi: 10.1053/jhin.2000.0819

9. National Advisory Committee for Laboratory Animal Research. Guidelines on the Care and Use of Animals for Scientific Purposes. Singapore; 2004. 


\section{El efecto de una solución superoxidada sobre el uroepitelio de la vejiga de ratas. Pérez-Salas Y. A., et al.}

10. Diario Oficial Mexicano. Especificaciones técnicas para la producción, cuidado y uso de los animales de laboratorio. NOM-062-ZOO-1999. 2001.

11. Rojo A. Cálculo del tamaño muestral en procedimientos de experimentación con animales. Valoración de las incidencias. Animales de Laboratorio. Revista de la Sociedad Española de las Ciencias del Animal de Laboratorio. 2014;62:31-33.

12. Diario Oficial Mexicano. Protección ambiental Salud ambiental - Residuos peligrosos biológicoinfecciosos - Clasificación y especificaciones de manejo. NOM-087-ECOL-SSA1-2002 2005.

13. Barron E, Thompson R. Specimen collection transport, and processing: Bacteriology. In: Manual of Clinical Microbiology. Washington, D.C: Ed. Murray PR; 2003. p. 320-1.

14. Murray MG, Thompson WF. Rapid isolation of high molecular weight plant DNA. Nucleic Acids Res. 1980;8(19):4321-5. doi: 10.1093/ nar/8.19.4321

15. Fierer N, Jackson JA, Vilgalys R, Jackson RB. Assessment of soil microbial community structure by use of taxon-specific quantitative PCR assays. Appl Environ Microbiol. 2005;71(7):4117-20. doi: 10.1128/ AEM.71.7.4117-4120.2005

16. Rolls G. Scientia Education Series: Microtomy and Paraffin Section Preparation. 2010.

17. Singal R, Dhar S, Zaman M, Singh B, Singh V, Sethi S. Comparative Evaluation of IntraOperative Peritoneal Lavage with Super Oxidized Solution and Normal Saline in Peritonitis Cases; Randomized Controlled Trial. Maedica (Bucur). 2016;11(4):277-85.
18. Altamirano AM. Reducing Bacterial Infectious Complications from Burn Wounds A look at the use of Oculus Microcyn60 to treat wounds in Mexico. Wounds. 2006; Suppl January:17-9.

19. Ni L, Zheng W, Zhang Q, Cao W, Li B. Application of slightly acidic electrolyzed water for decontamination of stainless-steel surfaces in animal transport vehicles. Prev Vet Med. 2016; 133:42-51. doi: 10.1016/j. prevetmed.2016.09.010

20. Game FL, Apelqvist J, Attinger C, Hartemann A, Hinchliffe RJ, Löndahl M, et al. Effectiveness of interventions to enhance healing of chronic ulcers of the foot in diabetes: a systematic review. Diabetes Metab Res Rev. 2016;32 Suppl 1:154-68. doi: 10.1002/dmrr.2707

21. Aras A, Karaman E, Yıldırım S, Yılmaz Ö, Kizıltan R, Karaman K. Intraperitoneal Infusion of Neutral-pH Superoxidized Solution in Rats: Evaluation of Toxicity and Complications on Peritoneal Surface and Liver. Med Sci Monit. 2017;23:960-5. doi: 10.12659/msm.899453

22. Waites KB, Chen Y, DeVivo MJ, Canupp KC, Moser SA. Antimicrobial resistance in gramnegative bacteria isolated from the urinary tract in community-residing persons with spinal cord injury. Arch Phys Med Rehabil. 2000;81(6):7649. doi: 10.1016/s0003-9993(00)90108-4

23. Waites KB, Canupp KC, Roper JF, Camp SM, Chen Y. Evaluation of 3 methods of bladder irrigation to treat bacteriuria in persons with neurogenic bladder. J Spinal Cord Med. 2006;29(3):217-26. doi: $10.1080 / 10790268.2006 .11753877$ 